\title{
Synthesis and electronic properties of alkyl- and alkyloxy-curcuminoids
}

\author{
Tahseen Abed Al Qader Alsalim a, Bahjat Ali Saeed a,*, \\ Rita Sabah Elias b, Hanna Sabeeh Abbo ${ }^{c}$ and Salam Jaber Titinchi c \\ a Department of Chemistry, College of Education, University of Basrah, Basrah-16001, Iraq \\ b Department of Pharmaceutical Chemistry, College of Pharmacy, University of Basrah-16001, Basrah, Iraq \\ c Department of Chemistry, University of the Western Cape, Bellville, Cape Town 7535, South Africa \\ *Corresponding author at: Department of Chemistry, College of Education, University of Basrah, Basrah-16001, Iraq. \\ Tel.: +964.0780.2410050; fax: +964.0443.3274766. E-mail address: bahjat.saeed@yahoo.com (B.A. Saeed).
}

\section{ARTICLE INFORMATION}

Received: 30 December 2012

Received in revised form: 01 February 2013

Accepted: 02 February 2013

Online: 31 March 2013

\section{KEYWORDS}

\section{Turmeric}

Tautomerism

Curcuminoids

Electronic transitions

Alkyloxy-curcuminoids

High resolution mass spectra

\section{Introduction}

Turmeric has been used in traditional medicine for the treatment of jaundice and other liver ailments, ulcers, parasitic infections, various skin diseases, sprains, inflammation of the joints, cold and flu symptoms. It is also used for preserving food as antimicrobial [1]. Curcumin, commonly called diferuloyl methane, is one of the minor constituents of turmeric which in addition to other analogs namely demethoxycurcumin (DMC) and bis-demethoxycurcumin (BDMC) is responsible for the medicinal activity of turmeric.

Curcumin is a hydrophobic polyphenol a bi- $\alpha, \beta$-unsaturated $\beta$-diketone structure that exhibits keto-enol tautomerism. It is a member of the linear diarylheptanoid class of natural products in which two oxy-substituted aryl moieties are linked together through a seven-carbon chain [2]. Its crystal structure was the subject of several papers which are agreed that the enol-form is the major tautomer of curcumin [3-5]. This picture was also supported by both spectral and theoretical studies [6-10].

One of the most important aspects of curcumin is its effectiveness against various types of cancer with both chemopreventive and chemotherapeutic properties. Properties exhibited by this compound include anti-inflamatory, antioxidant, antiviral, cutaneous wound healing hypocholestrolemic effects in adiabatic patients, anti-angiogenic, and stimulatory response to stress-induced biological activity [10].

The most important feature of curcumin is its lack of toxicity. Unlike most chemotherapeutic agents, curcumin has been shown in various animal models and human studies to be extremely safe even at very high doses with little to no toxicity (no dose-limiting toxicity at doses up to $10 \mathrm{~g} /$ day in humans) [11-13]. These properties make curcumin a valuable compound for drug development.
Despite these distinctive and unique properties its potential usage is limited due to poor bioavailability and poor selectivity that have been highlighted as major problems; and consequently search for a "super curcumin" without these problems and with efficacy equal to or better than that of curcumin is ongoing. Two strategies used in the search for alternative curcumin, namely (1) synthetic analogs or derivatives and (2) formulations. The first is the most explored and numerous synthetic curcumin analogs with a wide range of applications were described in literature [14-18].

To our knowledge the synthesis of curcumin analogs with alkyl and alkoxy chain substituents (other than methyl-, methoxy- and ethoxy- groups) at the flanking aromatic rings are not yet undertaken. It could be assumed that long alkyl- or alkyloxy- substituents may increases the values of hydrophobicity $\left(\log P_{\text {ow }}\right)$ for the derivatives leading to make them more available in the lipid tissues at which curcumin is known to work as an anti-oxidant.

\section{Experimental}

\subsection{Instrumentation}

Infrared spectra are recorded on Perkin-Elmer Spectrum 100 FTIR spectrometer, as ATR-Infra red spectra. The electronic spectra are measured at room temperature with $\mathrm{T}+$ 80 PG Instrument UV/Vis spectrophotometer in ethanol using quartz cells of $1 \mathrm{~cm}$ path length. Mass spectra are obtained on a HR Mass type Waters Synapt G2 MS by using Electrospray method. NMR spectra were recorded with Varian 500 (500 $\mathrm{MHz})$ and Varian $200(200 \mathrm{MHz})$ Spectrometer with tetramethyl silane (TMS) as an internal standard, $\delta$ scale in ppm, coupling constant in $\mathrm{Hz}$. 


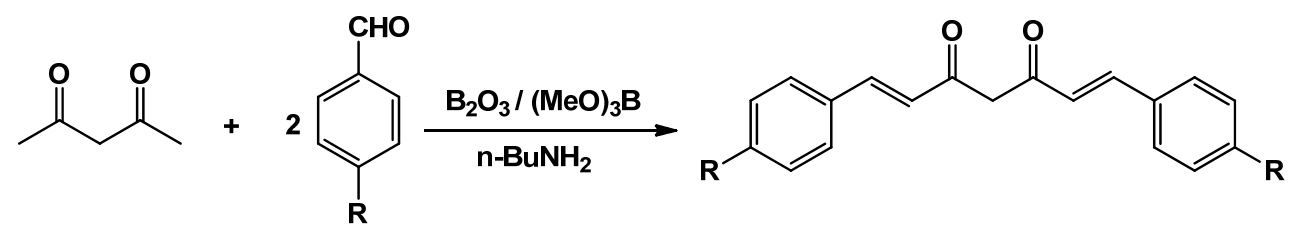

\begin{tabular}{cc}
\hline Compound & R \\
\hline 1 & $-\mathrm{C}_{3} \mathrm{H}_{7}$ \\
2 & $-\mathrm{C}_{5} \mathrm{H}_{11}$ \\
3 & $-\mathrm{C}_{6} \mathrm{H}_{13}$ \\
4 & $-\mathrm{C}_{8} \mathrm{H}_{17}$ \\
5 & $-0 \mathrm{C}_{3} \mathrm{H}_{7}$ \\
6 & $-0 \mathrm{C}_{7} \mathrm{H}_{15}$ \\
7 & $-0 \mathrm{C}_{8} \mathrm{H}_{17}$ \\
\hline
\end{tabular}

Scheme 1

\subsection{Theoretical calculations}

The quantum chemical calculations were performed using the Firefly QC package [19] which is partially based on the GAMESS (US) source code [20]. Geometrical optimizations were carried out using Density Functional Theory (DFT) method at B3LYP/6-31G(d) level of theory.

\subsection{Synthesis}

Acetylacetone $2.5 \mathrm{~g}(0.023 \mathrm{~mol})$ and boric oxide $1.2 \mathrm{~g}$ $(0.017 \mathrm{~mol})$ were stirred for 1 hour. The appropriate aldehyde (0.046 mol) was dissolved in dry dimethylacetamide (DMA) $(50 \mathrm{~mL})$, heated in water bath at $80{ }^{\circ} \mathrm{C}$, and tri methyl borate 5 $\mathrm{g}(0.046 \mathrm{~mol})$ were added to the complex. The reaction mixture was stirred for $5 \mathrm{~min}$. followed by a dropwise addition of a solution of $n$-butylamine $0.737 \mathrm{~g}(0.01 \mathrm{~mol})$ in DMA over a period of 1 hour. The mixture was stirred for further 3 hours. The solution was set aside overnight. Acetic acid (5 N, $70 \mathrm{~mL})$ at $80{ }^{\circ} \mathrm{C}$ was then added, and the mixture stirred for 1 hour. The mixture cooled and the solid product was collected by filtration, and then washed by hot water twice time, dried then recrystallized from the appropriate solvent (Scheme 1).

(1E,6E)-1,7-bis(4-propylphenyl)hepta-1,6-diene-3,5-dione

(1): Color: Yellow needles, recrystallized from ethanol. Yield: 56\%. M.p.: $139-141^{\circ} \mathrm{C} .{ }^{1} \mathrm{H}$ NMR $\left(200 \mathrm{MHz}, \mathrm{CDCl}_{3}, \delta\right.$ ppm): 0.95 $\left(6 \mathrm{H}, \mathrm{t}, J=7.8 \mathrm{~Hz}, \mathrm{CH}_{3}\right), 1.65\left(4 \mathrm{H}, \mathrm{m}, J=7.8 \mathrm{~Hz}, \mathrm{CH}_{2}\right), 2.61(4 \mathrm{H}, \mathrm{t}, J$ $\left.=7.8 \mathrm{~Hz}, \mathrm{CH}_{2}\right), 5.82(2 \mathrm{H}, \mathrm{s}$, vinylic $\mathrm{H}), 6.59(2 \mathrm{H}, \mathrm{d}, J=16.2 \mathrm{~Hz}$, $\mathrm{C} H=\mathrm{C}$ ), $7.20(4 \mathrm{H}, \mathrm{d}, J=7.8 \mathrm{~Hz}, \mathrm{Ar}-\mathrm{H}), 7.47$ ( $4 \mathrm{H}, \mathrm{d}, J=8.4 \mathrm{~Hz}, \mathrm{Ar}-$ $\mathrm{H}), 7.64(2 \mathrm{H}, \mathrm{d}, J=16.2 \mathrm{~Hz}, \mathrm{CH}=\mathrm{C}) .{ }^{13} \mathrm{C}$ NMR $\left(75 \mathrm{MHz}, \mathrm{CDCl}_{3}, \delta\right.$ ppm): 13.7, 24.3, 37.3, 101.5, 123.1, 128.1, 129.0, 132.5, 140.5, 145.3, 183.3. IR (ATR, v, cm-1): 3264, 2956, 2869, 1624, 1568, $1463,1417,1324,970,816,764$. MS (70 eV, $m / z): 360.2(\mathrm{M})$, 324.2, 317.2, 299.1, 254.1, 241.1, 213.1, 197.1, 173.1, 157.1, $133.1,115.1,91.0,69.1$.

(1E,6E)-1,7-bis(4-pentylphenyl)hepta-1,6-diene-3,5-dione (2): Color: Yellow needles, recrystallized from ethanol. Yield: 50\%. M.p: $122-124{ }^{\circ} \mathrm{C} .{ }^{1} \mathrm{H}$ NMR $\left(200 \mathrm{MHz}, \mathrm{CDCl}_{3}, \delta \mathrm{ppm}\right): 0.87$ $\left(6 \mathrm{H}, \mathrm{t}, J=6.6 \mathrm{~Hz}, \mathrm{CH}_{3}\right), 1.32\left(8 \mathrm{H}, \mathrm{m}, \mathrm{CH}_{2}\right) 1.56\left(4 \mathrm{H}, \mathrm{m}, \mathrm{CH}_{2}\right), 2.62$ $\left(4 \mathrm{H}, \mathrm{t}, J=8 \mathrm{~Hz}, \mathrm{CH}_{2}\right), 5.82(2 \mathrm{H}, \mathrm{s}$, vinylic $\mathrm{H}), 6.59(2 \mathrm{H}, \mathrm{d}, J=15.8$ $\mathrm{Hz}, \mathrm{CH}=\mathrm{C}), 7.20(4 \mathrm{H}, \mathrm{d}, J=8 \mathrm{~Hz}, \mathrm{Ar}-\mathrm{H}), 7.48(4 \mathrm{H}, \mathrm{d}, J=8 \mathrm{~Hz}, \mathrm{Ar}-$ $\mathrm{H}), 7.64(2 \mathrm{H}, \mathrm{d}, J=16 \mathrm{~Hz}, \mathrm{CH}=\mathrm{C}) .{ }^{13} \mathrm{C}$ NMR $\left(75 \mathrm{MHz}, \mathrm{CDCl}_{3}, \delta\right.$ ppm): 13.9, 22.5, 30.9, 31.4, 35.8, 101.5, 123.1, 128.1, 129.0, 132.4, 140.5, 145.6, 183.3. IR (ATR, v, $\mathrm{cm}^{-1}$ ): 3250, 2953, 2922, 1626, 1567, 1454, 1417, 1275, 1139, 1018, 972, 874, 812, 764. MS (70 eV, $m / z): 416.3(\mathrm{M}), 398.3,368.3,345.2,327.2,304.1$, 285.1, 257.1, 201.1, 185.1, 161.1, 131.0, 115.0, 95.4, 69.1.

(1E,6E)-1,7-bis(4-hexylphenyl)hepta-1,6-diene-3,5-dione (3): Color: Yellow needles, recrystallized from ethanol. Yield: $52 \%$. M.p: $118-120{ }^{\circ} \mathrm{C} .{ }^{1} \mathrm{H}$ NMR $\left(200 \mathrm{MHz}, \mathrm{CDCl}_{3}, \delta \mathrm{ppm}\right): 0.88(6 \mathrm{H}, \mathrm{t}$,
$\left.J=6.6 \mathrm{~Hz}, \mathrm{CH}_{3}\right), 1.30\left(8 \mathrm{H}, \mathrm{m}, \mathrm{CH}_{2}\right), 1.57\left(8 \mathrm{H}, \mathrm{m}, \mathrm{CH}_{2}\right), 2.62(4 \mathrm{H}, \mathrm{t}$, $\left.J=7.8 \mathrm{~Hz}, \mathrm{CH}_{2}\right), 5.82(2 \mathrm{H}, \mathrm{s}$, vinylic $\mathrm{H}), 6.59(2 \mathrm{H}, \mathrm{d}, J=15.8 \mathrm{~Hz}$, $\mathrm{CH}=\mathrm{C}), 7.20(4 \mathrm{H}, \mathrm{d}, J=8 \mathrm{~Hz}, \mathrm{Ar}-\mathrm{H}), 7.48(4 \mathrm{H}, \mathrm{d}, J=8.4 \mathrm{~Hz}, \mathrm{Ar}-\mathrm{H})$, $7.64(2 \mathrm{H}, \mathrm{d}, J=16 \mathrm{~Hz}, \mathrm{CH}=\mathrm{C}) .{ }^{13} \mathrm{C}$ NMR $\left(75 \mathrm{MHz}, \mathrm{CDCl}_{3}, \delta \mathrm{ppm}\right):$ 14.0, 22.5, 28.9, 31.2, 31.6, 35.9, 101.5, 123.1, 128.1, 129.0, 132.4, 140.5, 145.6, 183.3. IR (ATR, $v, \mathrm{~cm}^{-1}$ ): 3244, 2921, 2852, $1623,1604,1565,1455,1417,1275,1181,1139,1017,973$, 873, 824, 764. MS (70 eV, $m / z): 444.3$ (M), 416.3, 398.3, 359.2 341.2, 320.2, 289.1, 255.1, 236.2, 215.1, 197.1, 175.1, 157.0, $131.0,109.1,91.1$.

(1E,6E)-1,7-bis(4-octylphenyl)hepta-1,6-diene-3,5-dione (4): Color: Yellow needles, recrystallized from ethanol. Yield: $47 \%$. M.p: $130-131{ }^{\circ} \mathrm{C} .{ }^{1} \mathrm{H}$ NMR $\left(200 \mathrm{MHz}, \mathrm{CDCl}_{3}, \delta \mathrm{ppm}\right): 0.87(6 \mathrm{H}, \mathrm{t}$, $\left.J=7 \mathrm{~Hz}, \mathrm{CH}_{3}\right), 1.28\left(8 \mathrm{H}, \mathrm{m}, \mathrm{CH}_{2}\right), 1.57\left(16 \mathrm{H}, \mathrm{m}, \mathrm{CH}_{2}\right), 2.62(4 \mathrm{H}, \mathrm{t}$, $\left.J=7.6 \mathrm{~Hz}, \mathrm{CH}_{2}\right), 5.82(2 \mathrm{H}, \mathrm{s}$, vinylic $\mathrm{H}), 6.59(2 \mathrm{H}, \mathrm{d}, J=16.2 \mathrm{~Hz}$, $\mathrm{CH}=\mathrm{C}), 7.20(4 \mathrm{H}, \mathrm{d}, J=8 \mathrm{~Hz}, \mathrm{Ar}-\mathrm{H}), 7.47(4 \mathrm{H}, \mathrm{d}, J=8.4 \mathrm{~Hz}, \mathrm{Ar}-\mathrm{H})$, $7.64(2 \mathrm{H}, \mathrm{d}, J=15.8 \mathrm{~Hz}, \mathrm{CH}=\mathrm{C}) .{ }^{13} \mathrm{C}$ NMR $\left(75 \mathrm{MHz}, \mathrm{CDCl}_{3}, \delta\right.$ ppm): 14.0, 22.6, 29.2, 29.3, 29.4, 31.2, 31.8, 35.9, 101.5, 123.1 128.1, 129.0, 132.4, 140.5, 145.6, 183.0. IR (ATR, v, cm-1): 3244, 2955, 2918, 2848, 1623, 1604, 1567, 1468, 1417, 1369, 1275 1139, 1017, 973, 873, 819, 749, 716. MS (70 eV, $m / z): 500.4$ (M), 472.4, 444.4, 404.4, 369.4, 341.2, 317.2, 283.1, 256.1, 215.1, 185.1, 157.1, 131.0, 105.1, 80.0, 57.1.

(1E,6E)-1,7-bis(4-propyloxyphenyl)hepta-1,6-diene-3,5-dione (5): Color: Orange needles, recrystallized from ethanol. Yield: 50 \%. M.p: $142-144{ }^{\circ} \mathrm{C} .{ }^{1} \mathrm{H}$ NMR $\left(200 \mathrm{MHz}, \mathrm{CDCl}_{3}, \delta \mathrm{ppm}\right): 1.04$ $\left(6 \mathrm{H}, \mathrm{t}, J=7.2 \mathrm{~Hz}, \mathrm{CH}_{3}\right), 1.82\left(4 \mathrm{H}\right.$, sixtet, $\left.J=7.2 \mathrm{~Hz}, \mathrm{CH}_{2}\right), 3.96$ $\left(4 \mathrm{H}, \mathrm{t}, J=6.6 \mathrm{~Hz}, \mathrm{CH}_{2}\right), 5.82(2 \mathrm{H}, \mathrm{s}$, vinylic $\mathrm{H}), 6.49(2 \mathrm{H}, \mathrm{d}, J=$ $15.6 \mathrm{~Hz}, \mathrm{CH}=\mathrm{C}), 6.90(4 \mathrm{H}, \mathrm{d}, J=8.4 \mathrm{~Hz}, \mathrm{Ar}-\mathrm{H}), 7.49(4 \mathrm{H}, \mathrm{d}, J=9$ $\mathrm{Hz}, \mathrm{Ar}-\mathrm{H}), 7.61(2 \mathrm{H}, \mathrm{d}, J=15.6 \mathrm{~Hz}, \mathrm{CH}=\mathrm{C}) .{ }^{13} \mathrm{C}$ NMR $(75 \mathrm{MHz}$, $\left.\mathrm{CDCl}_{3}, \delta \mathrm{ppm}\right): 25.9,31.7,68.1,114.6,127.5,128.7,165.1$, 174.3, 183.1. IR (ATR, v, $\mathrm{cm}^{-1}$ ): 3310, 2957, 2878, 1620, 1600 1573, 1495, 1421, 961, 836, 750. MS (70 eV, $\mathrm{m} / \mathrm{z}): 392.2$ (M), 374.2, 353.4, 331.2, 313.3, 296.1, 279.1, 256.1, 229.1, 213.1, 189.1, 147.0, 131.1, 107.1, 83.1, 69.1.

(1E,6E)-1,7-bis(4-heptyloxyphenyl)hepta-1,6-diene-3,5-dione (6): Color: Orange needles, recrystallized from ethanol. Yield: $48 \%$. M.p: $118-120{ }^{\circ} \mathrm{C} .{ }^{1} \mathrm{H}$ NMR $\left(200 \mathrm{MHz}, \mathrm{CDCl}_{3}, \delta\right.$ ppm): 0.89 $\left(6 \mathrm{H}, \mathrm{t}, J=6.6 \mathrm{~Hz}, \mathrm{CH}_{3}\right), 1.42\left(12 \mathrm{H}, \mathrm{m}, \mathrm{CH}_{2}\right), 1.79\left(8 \mathrm{H}, \mathrm{m}, \mathrm{CH}_{2}\right)$, $3.98\left(4 \mathrm{H}, \mathrm{t}, J=6.6 \mathrm{~Hz}, \mathrm{CH}_{2}\right), 5.77(2 \mathrm{H}, \mathrm{s}$, vinylic $\mathrm{H}), 6.49(2 \mathrm{H}, \mathrm{d}, J$ $=15.8 \mathrm{~Hz}, \mathrm{C} H=\mathrm{C}), 6.90(4 \mathrm{H}, \mathrm{d}, J=8.8 \mathrm{~Hz}, \mathrm{Ar}-\mathrm{H}), 7.49(4 \mathrm{H}, \mathrm{d}, J=$ $8.8 \mathrm{~Hz}, \mathrm{Ar}-\mathrm{H}), 7.61(2 \mathrm{H}, \mathrm{d}, J=16.0 \mathrm{~Hz}, \mathrm{CH}=\mathrm{C}) .{ }^{13} \mathrm{C}$ NMR $(75 \mathrm{MHz}$ $\left.\mathrm{CDCl}_{3}, \delta \mathrm{ppm}\right): 14.0,22.5,25.3,29.0,31.7,68.1,141.8,127.5$, 129.7, 165.1, 174.3, 183.3. IR (ATR, v, $\mathrm{cm}^{-1}$ ): 3246, 3915, 2825 $1620,1600,1573,1510,1469,1325,1254,1182,1171,1076$, 972, 959, 813, 764, 721. MS (70 eV, $m / z): 504.7$ (M), 486.4, 462.4, 436.4, 408.3, 388.2, 312.2, 285.1, 158.1, 232.2, 205.2, 1731, 147.0, 107.1, 80.1, 57.1. 
Table 1. Calculated and observed band maxima and intensities of compound 5.

\begin{tabular}{llll}
\hline Excited state & Theoretical $\boldsymbol{\lambda}, \mathbf{n m}$ & Oscillator strength & Experimental $\boldsymbol{\lambda}$, nm \\
\hline $\mathrm{H}-3 \rightarrow \mathrm{L}$ & 438 & 0.0000 & Not observed \\
$\mathrm{H}-3 \rightarrow \mathrm{L}+1$ & & & \\
$\mathrm{H}-3 \rightarrow \mathrm{L}+4$ & & & \\
$\mathrm{H}-3 \rightarrow \mathrm{L}+5$ & & & \\
$\mathrm{H}-3 \rightarrow \mathrm{L}+6$ & & 1.8561 & \\
$\mathrm{H}-3 \rightarrow \mathrm{L}+7$ & 395 & & 400 \\
\hline $\mathrm{H}-2 \rightarrow \mathrm{L}$ & & & \\
$\mathrm{H}-2 \rightarrow \mathrm{L}+4$ & & 0.1735 & 327 \\
$\mathrm{H}-1 \rightarrow \mathrm{L}+1$ & 334 & & \\
$\mathrm{H} \rightarrow \mathrm{L}$ & & & \\
$\mathrm{H}-1 \rightarrow \mathrm{L}$ & & \\
$\mathrm{H}-1 \rightarrow \mathrm{L}+1$ & & & \\
\hline
\end{tabular}

(1E,6E)-1,7-bis(4-octyloxyphenyl)hepta-1,6-diene-3,5-dione (7): Color: Orange needles, recrystallized from ethanol. Yield: 50 \%. M.p: $138-140{ }^{\circ} \mathrm{C} .{ }^{1} \mathrm{H}$ NMR $\left(200 \mathrm{MHz}, \mathrm{CDCl}_{3}, \delta \mathrm{ppm}\right): 0.88$ $\left(6 \mathrm{H}, \mathrm{t}, J=6.6 \mathrm{~Hz}, \mathrm{CH}_{3}\right), 1.29\left(8 \mathrm{H}, \mathrm{m}, \mathrm{CH}_{2}\right), 1.55\left(12 \mathrm{H}, \mathrm{m}, \mathrm{CH}_{2}\right)$, $1.77\left(4 \mathrm{H}, \mathrm{m}, \mathrm{CH}_{2}\right), 3.98\left(4 \mathrm{H}, \mathrm{t}, J=6.2 \mathrm{~Hz}, \mathrm{CH}_{2}\right), 5.77(2 \mathrm{H}, \mathrm{s}$, vinylic $\mathrm{H}), 6.49(2 \mathrm{H}, \mathrm{d}, J=15.8 \mathrm{~Hz}, \mathrm{CH}=\mathrm{C}), 6.90(4 \mathrm{H}, \mathrm{d}, J=8.8$ $\mathrm{Hz}, \mathrm{Ar}-\mathrm{H}), 7.25(4 \mathrm{H}, \mathrm{d}, J=8.0 \mathrm{~Hz}, \mathrm{Ar}-\mathrm{H}), 7.61(2 \mathrm{H}, \mathrm{d}, J=15.6 \mathrm{~Hz}$, $\mathrm{CH}=\mathrm{C}) .{ }^{13} \mathrm{C}$ NMR $\left(75 \mathrm{MHz}, \mathrm{CDCl}_{3}, \delta \mathrm{ppm}\right): 14.0,22.6,26.0,29.1$, 29.2, 29.3, 31.7, 68.1, 114.8, 121.6, 127.5, 129.7, 140.1, 160.9, 183.3. IR (ATR, $v, \mathrm{~cm}^{-1}$ ): 3325, 2921, 2851, 162, 1599, 1510, 1466, 1324, 1276, 1258, 1171, 1137, 972, 870, 829, 784, 750, 722. MS $(70 \mathrm{eV}, \mathrm{m} / z): 532.4(\mathrm{M}), 514.4,436.4,368.4,326.2$, 299.1, 259.1, 219.2, 189.1, 161.1, 133.1, 1.7.1, 83.1, 57.1.

\section{Results and discussion}

The synthetic rout for the studied compounds is shown in Scheme 1.

High resolution mass spectroscopy was used to determine the molecular formulae of the synthesized compounds. In all cases the difference of $m / z$ values between the measured and the calculated formula less than 5 parts per million.

The most striking signal for the formation of the curcuminoids from their precursors is the ethylinic linkages, which were confirmed by ${ }^{1} \mathrm{H}$ NMR spectra evident by the presence of the two doublets with $15-16 \mathrm{~Hz}$ coupling constants. The ${ }^{1} \mathrm{H}$ NMR spectra of the synthesized compounds are characterized by four main signals. The alkyl/alkoxy protons chemical shifts are within the range 2.60 and $3.90 \mathrm{ppm}$. The signals that appear at about $5.80 \mathrm{ppm}$ are in consistence with the chemical shifts of the enolic form vinylic protons that are characterizing the structures of $\beta$-diketones in general. The presence of this signal and the absence of the signal of the CO$\mathrm{CH}_{2}$-CO methylene group that characterizes the diketo form in $\beta$-diketones indicate that these compounds are present in the enolic form mainly. This is in agreement with both experimental and theoretical results which found that curcumin presents mainly in the enolic form. The olefinic protons in the alkyl and alkoxy substituted compounds have their signals within the ranges 6.49-7.61 and 6.59-764 ppm characterize. The signals of the aromatic protons appear at the range 6.90-7.49 ppm and are self-explanatory and could be simply distinguished from those of the olefinic protons by their $o$-coupling with $J$-coupling constants within the range 8-9 $\mathrm{Hz}$. ${ }^{13} \mathrm{C}$ NMR spectra aid further support to the enolic character of these compounds via two signals that appear at 101 and 183 $\mathrm{ppm}$. The first signal is attributed to the vinylic carbon (CO-C$\mathrm{CO}$ ) and the other is attributed to the carbonyl group that is a part of the intra-hydrogen bonded chelated central ring in the enolic form that are characterize the spectra of similar $\beta$ diketones. The IR spectra are in agreement with the enolic form of $\beta$-diketones due to the large shift in the stretching frequencies of the carbonyl group which appears in general at $1620-1626 \mathrm{~cm}^{-1}$ due to the formation of the intra-hydrogen bonded chelated central ring as well as the conjugation with the ethylenic linkages.

The electronic spectra of both the alkyl- and alkoxysubstituted compounds are essentially identical and characterized by three bands accordingly the spectra of the compound $\mathbf{5}$ is discussed as representative example. The spectrum of this compound is characterized by strong and composite bands at 218,246, 326 and $400 \mathrm{~nm}$ (in hexane) (Figure 1). According to their intensities these maxima (in all cases $\varepsilon$ is larger than $10^{4}$ ) are due to the electronic dipole allowed type $\pi-\pi^{*}$ excitation of its extended $\pi$-conjugation system. For the longer band this shift is $10 \mathrm{~nm}$. Most likely, the weak, electronic dipole forbidden $n-\pi^{*}$ bands are located somewhere under the main absorption bands. The relatively large wavelength bands of the spectra indicate that the compounds exist mainly as the enolic tautomer in the solution.

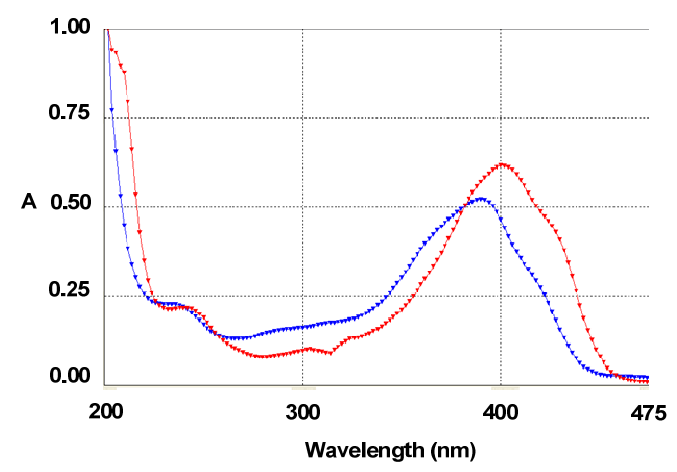

Figure 1. The UV-VIS spectrum of the compound 3 in ethanol (blue line with the band at $390 \mathrm{~nm}$ ) and in hexane (red line with the band at $400 \mathrm{~nm}$ ). In both cases the concentration is $2 \times 10^{-5} \mathrm{M}$.

In order to discuss the origin of the spectra, singlet excited-state calculations were done for compound $\mathbf{4}$ as representative for the rest since the spectra of the studied compounds (including both the methyl- and methoxysubstituted) are essentially identical. A theoretical study for the origin of the electronic transitions in curcuminoids is not previously done. Calculations were performed for compound 5 using Time Dependent-Self Consistent Field (TD-SCF) method on B3LYP/6-31G(d,p) optimized structures. The predicted spectra are in good agreement with the experimental spectra in hexane especially for the longer band at $400 \mathrm{~nm}$ which is the band that is responsible for the intense yellow colors of these compounds. The electronic transitions are comprise components of HOMO to LUMO as well other transitions like $\mathrm{H}-1$ to $\mathrm{L}+1, \mathrm{H}$ to $\mathrm{L}+1, \mathrm{H}-1$ to $\mathrm{L}, \mathrm{H}-2$ to $\mathrm{L}, \mathrm{H}-2$ to $\mathrm{L}+4$ and $\mathrm{H}-3$ to $(\mathrm{L}+4, \mathrm{~L}+5, \mathrm{~L}+6$ and $\mathrm{L}+7)$ as could be seen in Table 1 . The calculated band at $438 \mathrm{~nm}$ (with oscillator strength of 0.0000 ) may correspond to the $n-\pi^{*}$ band in these compounds and is not observable due to its location under the much more intense $\pi-\pi^{*}$. 


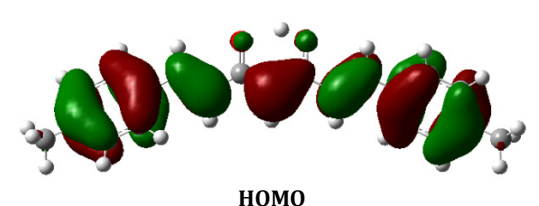

HОМо

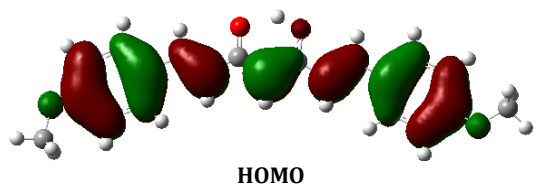

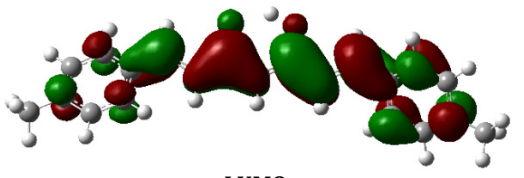

LUMO

A

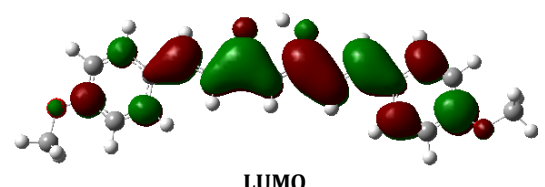

B

Figure 2. Representation of the HOMO and LUMO orbitals in the A) alkyl- and B) alkoxy-substituted curcuminoids determined by B3LYP/6-31G(d) level of theory.

In order to account for both the extended spectra of the curcuminoids and their similarity in alkyl- and alkoxysubstituted compounds the HOMO and the LUMO orbitals in these compounds were calculated at the B3LYP/6-31G(d) level of theory and are shown in Figure 2. The orbitals are $\pi$ character and are extended over the whole structures in both cases explaining the extended spectra of these compounds. On the other hand the orbitals in the alkyl- and alkoxy-substituted compounds are essentially identical which may accounts for the similarity of their spectra.

\section{Conclusion}

In this study alkyl- and alkoxy- substituted curcuminoids are prepared. The ${ }^{1} \mathrm{H}$ and ${ }^{13} \mathrm{C}$ NMR, IR, and UV-VIS spectra of the studied compounds are essentially identical for the alkyland the alkoxy-derivatives and indicate that these compounds exist mainly in the enolic form. The electronic spectra could be theoretically reproduced to fairly match the experimental spectra using the B3LYP/6-31G(d) level of theory. The close similarity of the electronic spectra of the two series of compounds is due to the close similarity of their frontier orbitals.

\section{References}

[1]. Anand, P.; Thomas, S. G.; Kunumakkara, A. B.; Sundaram, C.; Harikumar, K. B.; Sung, B.; Tharakan, S. T.; Misra, K.; Priyadarsini, I. K.; Rajasekharan, K. N.; Aggarwal, B. B. Biochem. Pharmacol. 2008, 76, 1590-1611.

[2]. Lagisetty, P.; Powell, D. R.; Awasthi, V. J. Mol Struct. 2009, 936, 23-28.

[3]. Tonnesen, H. H.; Karlsen, J.; Mostad, A. Acta Chem. Scand. B 1982, 36, 475-479.

[4]. Parimita, S. P.; Ramshankar, Y. V.; Suresh, S.; Row, T. N. G. Acta Cryst. E 2007, 63, 860-862.

[5]. Ishigami, Y.; Goto, M.; Masuda, T.; Suzuki, S. J. Jpn. Soc. Colour Mater. 1999, 72, 71-77.

[6]. Pyton, F.; Sandusky, P.; Alworth, W. L. J. Natural Prod. 2007, 70, 143146.

[7]. Balasubramanian, K. J. Agric. Food Chem. 2006, 54, 3512-3520.

[8]. Shen, L.; Zhang, H-Y.; Ji, H-F. Org. Lett. 2005, 7, 243-246.

[9]. Kong, L.; Priadarsini, K. I.; Zhang, H-Y. Theochem. 2005, 684, 111-116.

[10]. Benassi, R.; Ferrari, E.; Lazzari, S.; Spagnolo, F.; Saladini, M. J. Mol. Str. 2008, 892, 168-176.

[11]. Amolins, M. W.; Peterson, L. B.; Blagg, B. S. Bioorg. Med. Chem. 2009, 17, 360-367.

[12]. Ahn, C. M.; Park, B-G.; Wooa, H. B.; Hamc, J.; Shin, W-S. , Lee, S. Bioorg. Med. Chem. 2009, 19, 1481-1483.

[13]. Ke, D.; Wang, X.; Yang, Q.; Niu, Y.; Chai, S.; Chen, Z.; An, X.; Shen, W. Langmuir 2011, 27, 14112-14117.

[14]. Adhikary, R.; Barnes, C. A.; Trampel, R. L.; Wallace, S. J.; Kee, T. W.; Petrich, J. W. J. Phys. Chem. 2011, 115, 10707-10714.

[15]. Shao, W-Y.; Cao, W-N.; Yu, Z-W.; Pan, W-J.; Qiu, X.; Bu, X-Z.; An, L-K.; Huang, Z-H.; Gu, L-Q.; Chan, A. S. C. Tetrahedron Lett. 2006, 47, 40854089.
[16]. Qiu, X.; Liu, Z.; Shaw, W-I.; Liu, X.; Jing, D-B.; Yu, Y-J.; An, L-K.; Huang, SL.; Bu, X-Z.; Huang, Z-S; Gu, L-Q. Bioorg. Med. Chem. 2008, 16, 8035 8041.

[17]. Fuchs, J. R.; Pandit, B.; Bhasin, D.; Etter, J. P.; Regan, N.; Abdelhamid, D.; Li, C.; Lin, J.; Li, P-K. Bioorg. Med. Chem. Lett. 2009, 19, 2065-2069.

[18]. Ferrari, E.; Lazzari, S.; Marverti, G.; Pignedoli, F.; Saladini, F. Bioorg. Med. Chem. 2009, 17, 3043-3052.

[19]. Granovsky, A. A. Firefly version 7.1.G, http://classic.chem.msu/gran/firefly/index.html

[20]. Scmidt, M. W.; Baldridge, K. K.; Boatz, J. A.; Albert, S. T.; Gordon, M. S. Jensen, J. H.; Koseki, S.; Matsunaga, N.; Nguyen, K. A.; Su, S.; Windus, T. L.; Dupuis, M.; Montgomery, J. A. J. Comput. Chem. 1993, 14, 1347 1363. 